\title{
Synthesis Carboxyl Methyl Cellulose (CMC) from Rice Straw (Oryza Sativa L.) Waste
}

\author{
Masrullita $^{1}$, Rizka Nurlaila ${ }^{1}$, Zulmiardi $^{2}$, Ferri Safriwardy $^{2}$, Auliani $^{1}$, Meriatna $^{1 *}$ \\ ${ }^{1}$ Department of Chemical Engineering, Faculty of Engineering, Universitas Malikussaleh, Aceh, Indonesia \\ ${ }^{2}$ Department of Mechanical Engineering, Faculty of Engineering, Universitas Malikussaleh, Aceh, Indonesia \\ *Corresponding author E-mail: meriatna@ unimal.ac.id
}

\begin{abstract}
Manuscript received 29 October 2021; revised 10 Nov 2021; accepted 1 Jan 2022. Date of publication 10 Jan 2022
Abstract

Rice straw is one of material containing cellulose to produce Carboxymethyl Cellulose (CMC). CMC is a non toxic polysaccharide that produces from cellulose that widely used in the pharmaceutical, food, textile, detergent, and cosmetic products industries. There are two stages usually use to produce CMC which are mercerization and esterification processes. Rice straw waste is one of the materials to produce CMC, it has a cellulose content of $37.7 \%$, hemi-cellulose $21.99 \%$, and lignin $16.62 \%$. BPS Aceh shown that the total rice harvested area was 310.01 hectares, with a total production of 1.71 million tons, and rice produced at 982.57 thousand ton. This study aims to reduce waste and environmental pollution caused by rice straw and collects information of rice straw as a basic material to produce of carboxymethyl cellulose and to increase the economic value of rice straw. The effects of various wieght parameters sodium monochloroacetate on chemical properties of CMC that produce from rice straw were investigated in this research. Rice straw was collected from a rice field in Nisam, North Aceh. The research conducted by synthesizing 5 grams rice straw for 5.5 hours using $\mathrm{NaOH}$ and Sodium Monochloroacetate solutions. With variations weight of sodium monochloroacetate are 5,6,7,8 and 9 grams. The characterization of CMC was carried out by Fourier Transform Infrared (FTIR), CMC yield, DS, Viscosity, water content, pH. The result shows that addition of sodium monochloroacetate was significant factors influence the chemical properties on CMC. The CMC that produced in this study achieved to National Indonesia Standard (SNI).
\end{abstract}

Keywords: CMC, NaOH, Rice Straw, Synthesis, Sodium Monochloroacetate.

\section{Introduction}

Rice straw is a most available agro-industrial waste in Indonesia [1]which produced from the rice plant whose fruit (grain) is taken after being harvested and leaves only the stems and leaves so that rice straw becomes the largest agricultural waste. Even though the burning of rice straw waste was have a negative consequences including: loss of useful organic matter and environmental pollution. BPS Aceh [2] shown in 2019 determines that the total rice harvested area was 310.01 hectares, with a total production of 1.71 million tons, and rice produced at 982,57 thousand ton.

Carboximethyl Cellulose (CMC) is one of the cellulose derivatives compounds [3] hydrophilic colloid which is soluble in water that is effective for binding water so as to provide a uniform texture, increase viscosity, and tend to limit swelling [4], widely used in the pharmaceutical, food, textile, detergent, and cosmetic products industries.

Pitaloka et.al. [5] used $\mathrm{NaOH}$ base which functions to activate cellulose in water hyacinth plants, then a carboxymethylation reaction was carried out and produced a purity of $90.9 \%$ with an isopropanol-isobutanol composition of 80:20 (v/v). Abdulhameed et.al. [6] successfully isolated cellulose from rice husks using $\mathrm{NaOh}$ with a concentration of $30 \%(\mathrm{w} / \mathrm{v})$. Prasetia et.al. [7] shown rice straw produce $91,95 \%$ alpha cellulose by using $3,5 \mathrm{~N} \mathrm{HCl}$ as hydrolyzing agent.

This study aims to reduce waste and environmental pollution caused by rice straw and provides information on the use of rice straw as a raw material for the manufacture of carboxymethyl cellulose to increase the economic value of rice straw. In this study, we will examine the reaction time of the $\mathrm{CMC}$ formation process on the quality of the carboxymethyl cellulose produced based on the parameters of the water content (\%), yield (\%), $\mathrm{pH}$, degree of substitution (Ds), and viscosity and determine the appropriate concentration of Sodium Monochloroacetate against the quality of the carboxymethyl cellulose (CMC) produced. 


\section{Literature Review}

\subsection{Rice Straw}

Rice production in the world ranks third of all cereals, after corn and wheat. However, rice is the main source of carbohydrates for the majority of the world's population. The average level of rice consumption in the world is $60 \mathrm{~kg} / \mathrm{cap} / \mathrm{year}$. Rice plants produce the main product of grain and also produces side product which form rice straw. The rice straw has a large potential to produce CMC. Pratiwi et.al [8] reported rice straw waste has a cellulose content of $37.7 \%$, hemi-cellulose $21.99 \%$, and lignin $16.62 \%$. Lignin on the plants have a functions as an adhesive for cellulose on the plants which need to separated in the cellulose isolation process

\subsection{Carboxymethylcellulose (CMC)}

Carboximethyl Cellulose (CMC) is one of the cellulose derivatives compounds [3] hydrophilic colloid which is soluble in water that is effective for binding water so as to provide a uniform texture, increase viscosity, and tend to limit swelling [4], widely used in the pharmaceutical, food, textile, detergent, and cosmetic products industries. CMC is an effective emulsifying agent. The emulsifying agent is colloid with the dispersed phase in the form of a liquid and the dispersed medium may the form of a solid, liquid or gas. In some food products can be classified as liquid emulsions. One of the important parameters in determining the quality of emulsified food products is the stability of the emulsion. There are two stages usually use to produce CMC which are mercerization and esterification processes. Carboxymethyl cellulose is a derivative compound formed by reaction with alkali acid and chloroacetic acid. Sodium carboxymethyl cellulose is a water-soluble anionic polymer derived from cellulose. The reaction mechanism to produce CMC consists of 2 stages:

Alkalization chain reaction proces :

Rselulosa $-\mathrm{OH}+\mathrm{NaOH} \rightarrow$ Rselulosa $-\mathrm{ONa}+\mathrm{H} 2 \mathrm{O}$

Carboxymethylization chain reaction proces :

Rselulosa $-\mathrm{ONa}+\mathrm{ClCH} 2 \mathrm{COONa} \rightarrow$ Rselulosa $-\mathrm{OCH} 2 \mathrm{COONa}+\mathrm{NaCl}$

\section{Research Method}

\subsection{Material}

Rice straw was collected from a rice field in Nisam, North Aceh. Before due to the synthesis of CMC, delignification was carry out in order to remove lignin from the material using delignification process, so that the result of this process was in the form of cellulose with considerable purity. The process is carried out by inserting 25 grams of rice straw powder into the Erlenmeyer. Rice straw powder was isolated using $15 \% \mathrm{NaOH}$ solution.

\subsection{Method}

To produced CMC 100ml isopropanol was pour into 5 grams of rice straw cellulose (figure 1a) and then added NaoH $20 \mathrm{ml}$ and homogenized at $60^{\circ} \mathrm{C}$ tempetature during 5,5 hours on a hot plate. Sodium monochloroacetate are used as a reagent with variations of 5,6,7,8 and 9 grams and immersed in a methanol solution Then the solution neutralized using of $90 \%$ acetic acid until pH 7 for $100 \mathrm{ml}$. Finally, mixture was filtered and the residue obtained was dried in an oven at a temperature of $60^{\circ} \mathrm{C}$ for 30 minutes, sieved and CMC characterizations are carried out. CMC that produce has shown in Figure $1 \mathrm{~b}$.
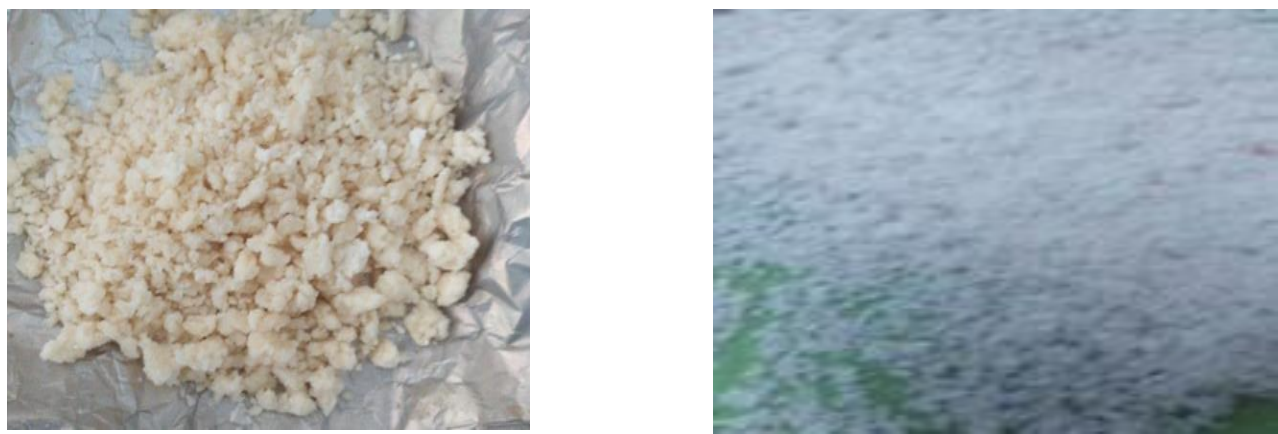

Fig 1. a. Cellulose. b. Carboximethyl Cellulose (CMC)

\subsection{Analysis and Measurement}

The prepared of CMC was characterizes in term of CMC yield, DS, Viscosity, water content, $\mathrm{pH}$ and FTIR.

CMC yield

The CMC was measure on dry weight.

$$
\text { Yield CMC }=\frac{\text { Weight CMC }}{\text { Weigth ricestraw cellulose }} \times 100 \%
$$

\subsection{Degree of substitution}

The degree of substitution was calculated according to Eqs (4) and (5) [9]. The calculation is based on the dry weight of the sample, before DS determined, are necessary to calculate the water content of the CMC. 


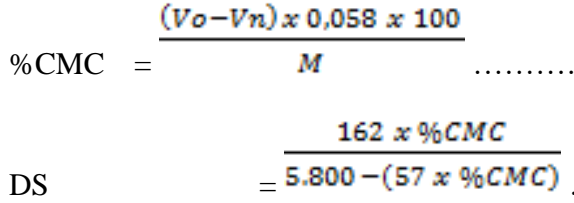

\subsection{Viscosity}

Viscosity analysis according to the Ostwald method, 1 gram of dry CMC is weighed included in a beaker of into 100 mL distilled water and then added that the amount calculated using the formula:

$\mu$ solution $=\frac{\mu \text { water } x \rho C M C x \text { t CMC }}{\rho \text { water xt water }}$.

\subsection{Water Content}

Moisture analyzer was used to shows the content of water, 1 gram sample put into a breaker and then put on moisture analyzer.

\subsection{Analysis of $\mathrm{pH}$}

1 gram sample added to $100 \mathrm{~mL}$ distilled water with $70^{\circ} \mathrm{C}$ temperature and mix using using magnetic stirrer until dissolve. Then pH meter put into solution.

\subsection{Fourier Transform Infrared (FTIR)}

FTIR Shimadzu IR Prestige-21 has been widely used cellulose research. This analyze used to determine the structure of organic compounds and also for quantitative analysis on the chemical composition during or after chemical treatments [10].

\section{Results And Discussions}

The investigations were carried out, to identify characteristics of CMC which is processed through the synthesis of rice straw waste. The study of synthesized CMC presented in Table.1 shows that the produced CMC due to the synthesis rice straw cellulose using the Sodium Monochloroacetate solutions are have a significant effect on the CMC.

Table 1. Characteristics of Carboxymethylcellulose from Rice Straw

\begin{tabular}{cccccc}
\hline $\begin{array}{c}\text { Sodium Monochloroacetate } \\
(\mathrm{gr})\end{array}$ & Yield (\%) & $\mathrm{pH}$ & $\begin{array}{c}\text { Water Content } \\
(\%)\end{array}$ & $\begin{array}{c}\text { Degree of Substitutions } \\
(\mathrm{Ds})\end{array}$ & $\begin{array}{c}\text { Viscosity } \\
(\mathrm{cP})\end{array}$ \\
\hline 5 & 62,4 & 7,2 & 18,18 & 0,18 & 1,074 \\
6 & 79 & 7,4 & 18,76 & 0.350 & 0,975 \\
7 & 97,6 & 7,5 & 19 & 0,634 & 0,98 \\
8 & 95 & 7,6 & 19,2 & 0,689 & 1,279 \\
9 & 87,8 & 7,8 & 20,14 & 0,78 & 1,285 \\
\hline
\end{tabular}

\subsection{Yield Percentage Due to Sodium Monochloroacetate Solutions}

Figure 2 shown the increasing occurs in the addition of 3 to 4 to 5 and in the other hand the addition of 8 and 9 grams weight sodium monochloroacetate shows a decreasing due to cellulose which is difficult to penetrate by carboxymethylation reagents so that it can produce side product [5] [11]. Melisa et.al [12] reported that the carboxymethylation process was affected by the number of sodium mono chloroacetate reagent.

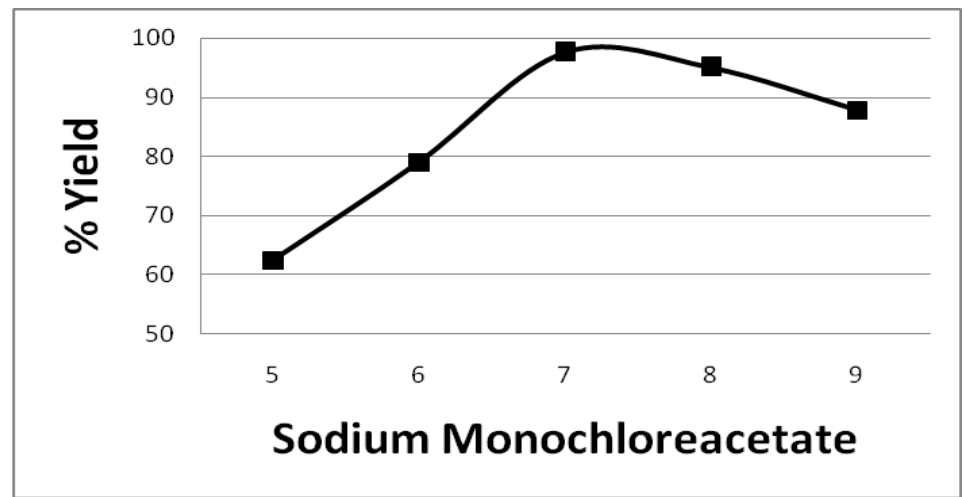

Fig 2. Percentage yield of CMC with various sodium monochloroacetate. 


\subsection{Analysis of pH Due to Sodium Monochloroacetate Solutions}

Figure 2 shows the relationship between the additions weight of sodium monocholoroacetate and $\mathrm{pH}$ which produce from carboxymethylization process. The increasing is related to the addition of weight of sodium monocholoroacetate. The higher addition of sodium monochloroacetate its cause the number $\mathrm{pH}$ increasing, the number $\mathrm{pH}$ value described how viscosity increase [13].

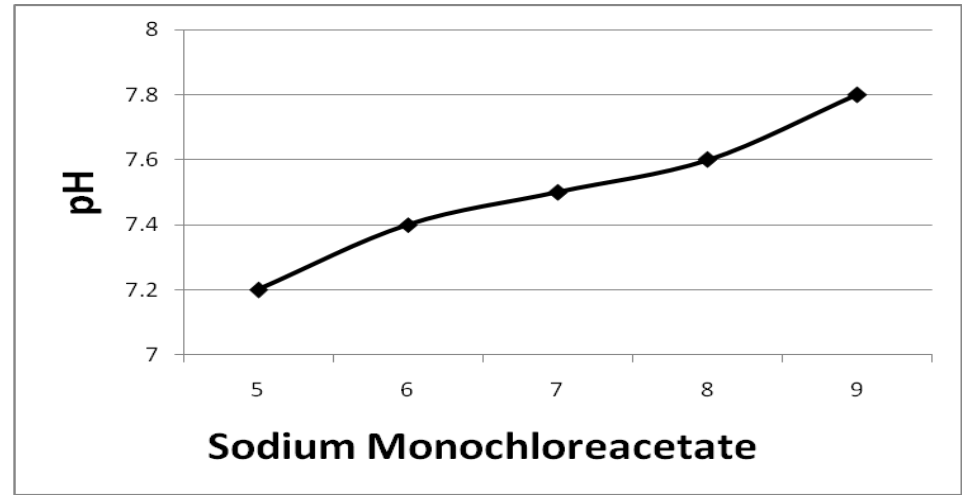

Fig 3. $\mathrm{pH}$ index of CMC with various sodium monochloroacetate.

\subsection{Analysis Content of Water}

From the results, it shows that the content of water was affected by addition of sodium monochloroacetate (see Figure 1). This investigation was observed that the highest value content of water achieve by using 6 grams weight sodium monochloroacetate $(20,14)$. This due to the ability of CMC bond in water so that water content will increase.

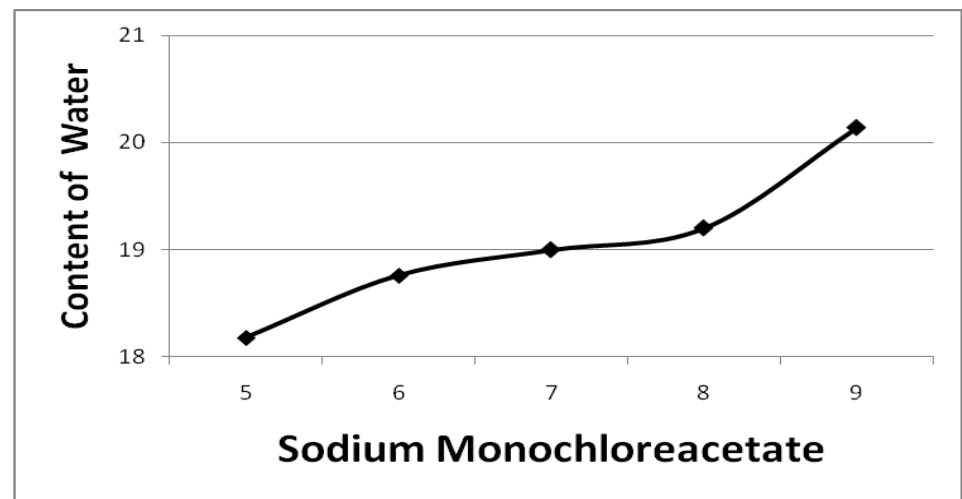

Fig 4. Percentage Content of water of CMC with various sodium monochloroacetate.

\subsection{Analysis of Degree of Substitution (DS)}

The effects of added sodium monochloroacetate on degree of substitution were presented in figure 5. It showed an increasing degree of substitution, from 0.18 to 0.35 to 0.63 to 0.68 and to 0.78 respectively. It's caused the heavier carboxymethyl groups have replaced the number of $\mathrm{OH}$ groups [14].

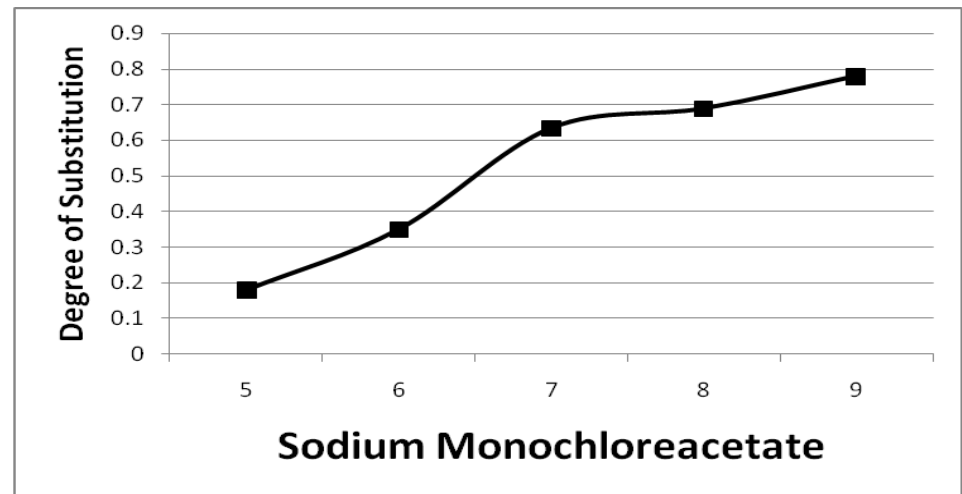

Fig 5. Degree of Substitution of CMC with various sodium monochloroacetate.

The degree of substitution is an important to determine the quality of CMC. The degree of substitution is an average number of the number of hydroxyl groups that are replaced into ether carboxylate groups in the formation of CMC, the higher the degree of substitution presented the better quality of CMC, because its solubility in water is getting better [12] [15] [16]. 


\subsection{Analysis of Viscosity}

Viscosity is the resistance caused by friction between the molecules on the liquid, which is able to resist the flow of fluid which can be declared as an indicator level of viscosity. The investigation shown the highest viscosity obtained highest value at $1,285 \mathrm{cP}$ with addition weight 9 grams of sodium monochloroacetate and the lower is $1,074 \mathrm{cP}$ with addition 5 gram of sodium monochloroacetate (see Figure 8). The groups that have been substituted with a methyl group then the CMC will reactive to water. According to Coniwanti et.al [17] the fluids that were previously free to move, it's restrained to move freely so that the state of the solution is better and there is an increasing in viscosity. The degree of substitution has a significant effect on viscosity [16].

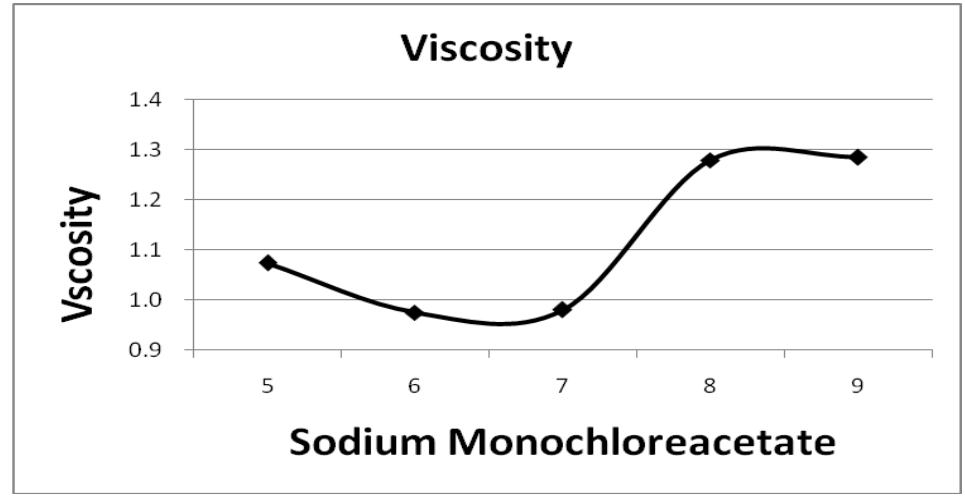

Fig 6. Viscosity of CMC with various sodium monochloroacetate.

\subsection{Fourier Transform Infrared (FTIR)}

The FTIR spectroscopy has shown in figure 7. The presence of new absorptions band FTIR characteristics on CMC the appearance of an absorption peak at wave number $3385.07 \mathrm{~cm}-1$ which is an $\mathrm{O}-\mathrm{H}$ group. According to Yeasmin and Mondal [18] this is caused by stretching vibrations carboxyl group $\left(\mathrm{COO}^{-}\right)$

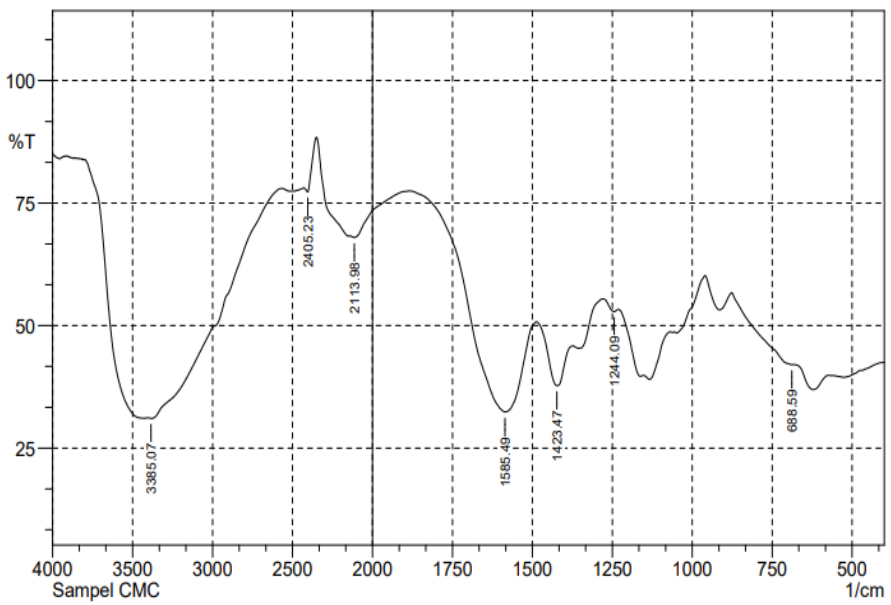

Fig 7. FTIR spectra of standard and prepared CMC with

Peak $2924.07 \mathrm{~cm}-1$ is attributable to $\mathrm{C} \mathrm{H}$ stretching. The peak at $3700-3100 \mathrm{~cm}-1$ is an $\mathrm{OH}$ group shown by the formation of a hydrogen bond group in another hydroxyl group of the $\mathrm{H} 2 \mathrm{O}$ molecule. At the absorption peak of 2113.98 indicates the presence of a $\mathrm{C}=\mathrm{C}$ group of alkynes in the absorption region of 2210-2280. The absorption peak of 1585.49 indicates the presence of nitro NO2 compounds in the absorption area of 1500-1570, according to Chen et.al [19] the CMC was successfully synthesized due to the cellulose molecule has replaced by carboxymethyl groups.

The appearance of vibrations at peak 1423.47 and 688.59 is a $\mathrm{C}-\mathrm{H}$ group. At peak 1423.47 indicates the presence of a carboxyl group. Based on this result that indicated CMC have similar functional group to commercial $\mathrm{Na}-\mathrm{CMC}$ and has a wave number that indicates the constituent group in $\mathrm{Na}-\mathrm{CMC}$ is the carboxyl group $-\mathrm{CH} 2$, Phan et.al [20] reported the degradation of hemicellulose caused by the reduction of hemicellulose its retained at high alkaline concentrations.

\section{Conclusions}

The cellulose extracted from rice straw waste can be produced to CMC using sodium monochloroacetate. Weigh of sodium monochloroacetate are a significance influence that affects the chemical properties of CMC that produce from rice straw waste. CMC was successfully produced and achieve SNI standart to use for pharmaceutical and food industries.

\section{Acknowledgement}

Financial support from The Malikussaleh University through the Lembaga Penelitian dan Pengabdian Kepada Masyarakat (LPPM) Unimal funding grant no: PNBP 21.01.FT.18 is acknowledge with gratitude. 


\section{References}

[1] Inayati, Abdulloh, and R.Z. Bagus, "Fabrication of Bioplastic from Rice Straw," Jurnal EQUILIBRIUM, vol. 4, 2020 , pp. 18-22.

[2] Badan Pusat Statistik Aceh, "Luas Panen dan Produksi Padi di Provinsi Aceh 2019," No. 15/03/1 1/Th. XXIII, 2020, pp. 1-12.

[3] P. Rodsamran and R. Sothornvit, "Carboxymethyl cellulose from rice stubble waste," Songklanakarin J. Sci. Technol, vol. 42, 2020, pp. 454-460.

[4] A. Purvitasari, "Kajian Pengaturan PH dan Penambahan CMC terhadap Kualitas Produk Sirup Nira Kelapa," 2004.

[5] A.B. Pitaloka, N.A. Hidayah, A.H. Saputra, and M. Nasikin, "Pembuatan CMC Dari Selulosa Eceng Gondok Dengan Media Reaksi Campuran Larutan Isopropanol-Isobutanol Untuk Mendapatkan Viskositas dan Kemurnian Tinggi," JURNAL INTEGRASI PROSES, vol. 5, 2015, pp. 108 - 114.

[6] A. Abdulhameed, H.M. Mbuvi, E.O. Changamu, and F.M. Maingi, "Microwave synthesis of Carboxymethylcellulose ( CMC ) from Rice Husk," IOSR Journal of Applied Chemistry (IOSR-JAC), vol. 12, 2019, pp. 33-42.

[7] I.G. Prasetia, I.D. Yuliandari, D.G. Ulandari, C.I. Arisanti, and A.A. Dewandari, "Evaluasi Kandungan Selulosa Mikrokristal Dari Jerami Padi (Oryza sativa L.) Varietas IR64," Jurnal Kimia, vol. 12, 2018, pp. 97-101.

[8] R. Pratiwi, D. Rahayu, and M.I. Barliana, "Pemanfaatan Selulosa dari Limbah Jerami Padi (Oryza sativa) sebagai Bahan Bioplastik," IJPST, vol. 3, 2016, pp. 83-.

[9] R. Futeri, "Synthesis Carboxyl Methyl Cellulose ( CMC ) with Addition Method from Durian Seed," Measurement, vol. 8, 2016, pp. 262-268.

[10] N. Laribi, S. Maatoug, Z. Jebali, R. Zouari, H. Majdoub, and M. Cheikhrouhou, "Low-Cost Carboxymethyl Holocellulose," CELLULOSE CHEMISTRY AND TECHNOLOGY, vol. 54, 2020, pp. 225-236.

[11] Nur'ain, Nurhaeni, and A. Ridhay, "Optimasi Kondisi Reaksi Untuk Sintesis Karboksimetil Selulosa ( CMC ) dari Batang Jagung ( Zea mays L.)," Jurnal Kovalen, vol. 3, 2017, pp. 112-121.

[12] Melisa, S. Bahri, and Nurhaeni, "Optimization Synthesis Corboxymethyl Cellulose Of Sweet Corn Cob (Zea Mays L Saccharata)," Jurnal of Natural Science, vol. 3, 2014, pp. 70-78.

[13] G.P. Murti, "PENGARUH pH TERHADAP SIFAT FISIK DAN STABILITAS FISIK GEL PADA GEL EKSTRAK ETANOLIK DAUN SIRIH MERAH," Universitas Gajah Mada, 2017.

[14] M.I. Mondal, M.S. Yeasmin, and M.S. Rahman, "Preparation of food grade carboxymethyl cellulose from corn husk agrowaste," Int. J. Biol. Macromol., vol. 79, 2015, pp. 144-150.

[15] M.K. Ferdiansyah, D.W. Marseno, and Y. Pranoto, "Kajian Karakteristik Karboksimetil Selulosa ( CMC ) dari Pelepah Kelapa Sawit sebagai Upaya Diversifikasi Bahan Tambahan Pangan yang Halal," Jurnal Aplikasi Teknologi Pangan, vol. 5, 2016, pp. 136139.

[16] R. Nur, Tamrin, and M.Z. Muzakkar, "Sintesis dan Karakterisasi CMC (Carboxymethyl Cellulose) yang Dihasilkan dari Selulosa Jerami Padi," Jurnal Sains dan Teknologi Pangan (JSTP), vol. 1, 2016, pp. 222-231.

[17] P. Coniwanti, M. Dani, and Z.S. Daulay, "Pembuatan Natrium Karboksimetil Selulosa (Na-CMC) Dari Selulosa Limbah Kulit Kacang Tanah (Arachis Hypogea L.)," vol. 21, 2015, pp. 57-64.

[18] M.S. Yeasmin and I.H. Mondal, "Synthesis of highly substituted carboxymethyl cellulose depending on cellulose particle size," International Journal of Biological Macromolecules, vol. 80, 2015, pp. 725-731.

[19] J. Chen, H. Li, C. Fang, Y. Cheng, T. Tan, and H. Han, "Synthesis and structure of carboxymethylcellulose with a high degree of substitution derived from waste disposable paper cups," Carbohydrate Polymers, vol. 237, 2020, pp. 1-7.

[20] M.T. Phan, T.T. La, and T.H. Ngo, "Study on extracting hemicellulose, cellulose, and carboxymethyl cellulose from Vietnamese rice straw waste," Vietnam Journal of Science, Technology and Engineering, vol. 63, 2021, pp. 15-20. 